\title{
Successful North Canterbury dairy conversion with quality pasture of nil endophyte ryegrass
}

\author{
C.B. SUTTON \\ Culverden
}

\section{Introduction}

I have been farming all my working life in partnership with my brother Graeme in a family company known as V.Q. Sutton \& Sons Ltd. While I managed our town supply dairy farm in Redwood Valley, west of Nelson, Graeme managed our sheep and beef farm at Kikiwa, near Nelson Lakes.

With the impending deregulation of the town supply industry and the growing realisation that our assets were held in high-value Nelson land, we diversified into horticulture, establishing 5 ha of kiwifruit, but we soon realised our strengths were in grassland farming.

As a result we began to look for dairying opportunities in Golden Bay and on the West Coast, but were persuaded by our accountant to look at North Canterbury properties, as this area offered the scope and controlled water supply that was lacking in other regions.

In January 1993, we purchased "Inniskillen", a 706 ha sheep and ebef property. In the following 7 months we converted the property to three dairy units, of about 200 effective hectares each with a $50 \%$ sharemilker. While the dairy farms were in development I lived at Inniskillen and supervised the project. Along with Graeme, I manage Inniskillen Farms Ltd today.

In 1994 we sold our sheep and beef farm in Nelson, and a year later we purchased another property in Culverden known as "Braeside". This is being converted into two dairy units, ready for milking in spring 1996. Both Graeme and I have supervised this conversion project.

\section{State of farm at purchase}

The farm fertility at the time of purchase was very low. Balmoral soils, which constitute the majority of the farm, are derived from weathered greywacke alluvium and gravels covered to varying depths with shallow loess. Such soils have inadequate nutrient status for successful grassland farming.

The farm was carrying $6000 \mathrm{SU}$ at $8.5 \mathrm{SU}$ per ha. Of the 706 ha, 250 ha under border dyke irrigation was just holding ryegrass and the balance could only be described as low quality native type dryland pasture.

\section{Development plan}

Our initial thought for the development was to develop one unit a year, but after having a feasibility study done by a Farmwise consultant, it was decided to do the three units at the same time.

Moving into a new district and bearing in mind the size of the conversion, we recognised the need to consult with both local and professional people on things like shelter requirements, pasture species, fertiliser, borderdyke design, herd size, dairy shed design and selecting sharemilkers. We received invaluable help from Farmwise Consultancy, Ravensdown field staff and AgResearch.

The borderdyking was contracted out, along with the fencing, the building of three cowsheds and three houses that were needed. The ground work prior to borderdyking and the sowing down afterwards were all carried out under our management by staff we employed. We also installed the water troughs to the existing water mains.

\section{Fertiliser}

\section{Initial soil test results - Jan/Feb 1993}

Below are the average results from eight blocks sampled in early 1993. There was very little variation in the results.

$$
\begin{array}{cccccc}
\mathrm{pH} & \text { Phosphorus } & \text { Potassium } & \text { Sulphur } & \text { Calcium } & \text { Magnesium } \\
5.9 & 9 & 7 & 6 & 8 & 10
\end{array}
$$

In making the initial decision on the fertiliser programme, the following assumptions were made:

1. Both the new and existing borderdyked areas on all units were seen as having the same base fertility.

2. The need to increase Olsen $P$ level to 20 in all areas as soon as possible. Phosphate applied was designed to reach this objective by way of a steady increase while allowing a return to be earned on the fertiliser dollars spent.

3. The recommendations were made on the basis that at least one further fertiliser application would be made prior to April 1994.

4. 6-9 $\mathrm{kg}$ ha of useful plant $\mathrm{P}$ required to lift Olsen test one point. 


\begin{tabular}{lccc}
\hline & Phosphate & Potassium & Sulphur \\
\hline $1993-94$ & 99 & 30 & 90 \\
$1994-95$ & 90 & 23 & 55 \\
$1995-96$ & 101 & 65 & 80 \\
Total & 290 & 118 & 225 \\
\hline
\end{tabular}

Soil test results: October 1995

Avg. of the three farms

$$
\begin{array}{cccccc}
\mathrm{pH} & \text { Phosphorus } & \text { Potassium } & \text { Sulphur } & \text { Calcium } & \text { Magnesium } \\
5.76 & 25 & 7 & 14 & 7 & 9
\end{array}
$$

\section{Nitrogen}

Owing to the large movement of soil during borderdyking and the low levels of available nitrogen, we found it necessary to apply nitrogen at regular intervals. Now that the nitrogen cycle has established on a new higher plane, nitrogen inputs are now based on feed demand and supply.

\section{Lime}

At the time of conversion, 2.5 tonnes per ha of good quality lime $(96-97 \%$ purity, $80 \%<1.18 \mathrm{~mm}$ ) was spread. We have $\mathrm{pH}$ tested every paddock on the farm since the initial application, and found them to be lower than the optimum level. Paddocks with $\mathrm{pH}$ of less that 5.5 have had 5 tonnes of lime, and those of $5.6-5.7 \mathrm{pH}$ have had 2.5 tonnes.

We have monitored the fertility levels very vigorously and will continue to do so, as I consider it to be very important in maintaining high levels of production.

\section{Pasture}

The pasture mix sown at Inniskillen was as follows:

$\begin{aligned} 10 \mathrm{~kg} & \text { Greenstone (nil endophyte) } \\ 8 \mathrm{~kg} & \text { Marsden or Nui (nil endophyte) } \\ 2 \mathrm{~kg} & \text { Pawera red clover } \\ 2 \mathrm{~kg} & \text { Pitau white clover } \\ 2 \mathrm{~kg} & \text { Timothy }\end{aligned}$

A similar mix was also used on the recently developed Braeside property.

\section{Why nil endophyte ryegrass?}

The conversion of a dryland sheep and beef farm to a borderdyked dairy farm was a steep enough learning curve for anyone, let alone sowing nil endophyte ryegrass in hot North Canterbury. However, after researching the pros and cons of endophyte versus nil endophyte, it was decided to take the risk of planting all nil endophyte ryegrass. We were swayed from observation of a palatability problem with our Nelson herd on high endophyte pasture, and the perceived increase in production by sowing nil endophyte grasses. Pasture persistence and farm performance have reinforced our original decision.

Although it has been difficult to maintain low endophyte ryegrass pasture for research comparison, there is growing evidence of a small but inconsistent production advantage to low endophyte pastures, especially where the proportion of clover in the pasture is low (Clark et al. 1996).

\section{Greenstone}

With high levels of fertility and good irrigation it was felt there were no barriers to achieving the greater production potential available from nil endophyte Grasslands Greenstone and perennial ryegrass. Only a modest increase in production was required to cover the cost of resowing if it became necessary.

\section{Timothy}

Timothy was observed growing naturally in hedgerows at Inniskillen. It has established well, is highly palatable and persistent, and performs very well in summer.

After establishment all new pastures were carefully monitored, predominantly for growth initially and then for the presence of Argentine stem weevil, grass grub and porina. This latter monitoring was conducted with the asistance of AgResearch scientists. Programmes based predominantly around rolling were developed to reduce the damage due to build-up of the grass grub population in year three pastures. Although porina populations have been moderate, the population density to date has not warranted a spray programme.

Although nil endophyte pastures are particularly susceptible to Argentine stem weevil attack, population densities have not been high possibly because of dense pasture and borderdyke irrigation. As a preventive measure the Argentine stem weevil parasitoid was released onto the pastures at Inniskillen in the autumn of 1995.

\section{Production}

The following table shows the actual production compared with the original budgets, along with the percentage of new pasture on each unit for the last 3 years. 


\begin{tabular}{lrrrrr}
\hline Unit & $\begin{array}{c}\text { Budget } \\
\mathrm{kg} / \mathrm{MS}\end{array}$ & $\begin{array}{c}\text { Actual } \\
\mathrm{kg} / \mathrm{MS}\end{array}$ & $\mathrm{kg} / \mathrm{ha}$ & $\begin{array}{r}\% \text { Ahead } \\
\text { of budget }\end{array}$ & $\begin{array}{r}\% \text { New } \\
\text { pasture }\end{array}$ \\
\hline $1993-94$ & & & & & \\
1 & 96000 & 135125 & 795 & $41.0 \%$ & $65.3 \%$ \\
2 & 110300 & 143504 & 755 & $30.0 \%$ & $31.6 \%$ \\
3 & 83660 & 122782 & 818 & $47.0 \%$ & $80.0 \%$ \\
\hline $1994-95$ & & & & & \\
1 & 102039 & 182903 & 1075 & $79.0 \%$ & $74.1 \%$ \\
2 & 112717 & 168853 & 888 & $48.8 \%$ & $41.1 \%$ \\
3 & 94920 & 156219 & 1041 & $64.6 \%$ & $84.4 \%$ \\
\hline 199596 & & & & & \\
1 & 113883 & 187000 & 1100 & $64.2 \%$ & $92.0 \%$ \\
2 & 124355 & 179600 & 945 & $44.4 \%$ & $53.7 \%$ \\
3 & 104720 & 165640 & 1035 & $58.2 \%$ & $100.0 \%$ \\
\hline
\end{tabular}

Our original production budgets were based on district expectations but were well exceeded in every year; in fact we achieved our predicted 5 th year budget in the first year.

\section{Conclusion}

\section{Soil fertility}

Soil nutrients status, as indicated by soil fertility tests, has lifted progressively with fertiliser and management input. While $\mathrm{pH}, \mathrm{Mg}$ and $\mathrm{K}$ status declined initially, these shortcomings have been addressed with lime and the addition of $\mathrm{Mg}$ to maintenance fertiliser. A trial to monitor changes in soil $\mathrm{K}$ status and long-term requirements for $\mathrm{K}$ has recently begun on two of the three dairy farms at Inniskillen.

\section{Pasture}

We believe that the species we have used at Inniskillen, and the pasture mix, are producing high amounts of top quality dry matter. The concern with the persistence of the nil endophyte ryegrasses has not been realised. Pasture production has increased each year. Some overdrilling has been done in areas affected by porina and grass grub.

In the first season pasture produced $10200 \mathrm{~kg} / \mathrm{DM}$ while in the 1995-96 season $14000 \mathrm{~kg} / \mathrm{DM}$ was grown. Units 1 and 3, with the higher percentage of new grass, have out-produced unit 2 by $117 \mathrm{~kg}$ MS per ha per year. Over the 3-year period, this equates to $67070 \mathrm{~kg} \mathrm{MS}$. Given an average payout of $\$ 3.40$ per $\mathrm{kg}$ MS, less the cost of regrassing, interest and buying in silage if we had regrassed all the old pasture in 1993, we would have had a net gain of $\$ 140918$.
While such a comparison is not strictly scientific, as each farm, while having herds of similar genetic merit did not have equal amounts of old and new pasture, it does serve to illustrate the different production potential of old versus new pasture species. It should be emphasised that the full potential of the new grass was not realised in the first years because of low stocking rates. Experience gathered has been used to establish far higher base stocking rates ( 2.7 vs 2.2 cows/ha) on the newly converted Braeside property. Because growth of new grass far exceeded all expectations, large amounts of old pasture were conserved as silage in the first season.

At the time it was considered important that there was adequate old pasture present on the farm to provide a standoff area in the first spring if conditions were wet and to provide a source of supplementary feed in the preceding autumn. Some 1200 fresh tonnes of silage was made from 250 ha of old pasture in the autumn preceding the first season. There was also some concern about the ability of new pasture to perform in the first spring.

\section{Animal health}

In the first two seasons the sharemilkers recorded some bloat, as expected with the usual dominance of clover on a conversion farm. While soil tests showed the need for extra potassium, this only exacerbated the bloat problem over the summer-autumn period. Subsequent seasons have seen a rapid progression to ryegrass dominance in the pasture, and the bloat problem is now manageable.

\section{New conversion - Braeside}

People often ask "What would you do differently if you did it all again?" In our new conversion at Braeside we have regrassed the whole farm with nil endophyte grasses. Embassy ryegrass has been added to the mix to give earlier spring growth. Also, in our drive for maximium production in the shortest possible time, we aim to achieve an Olsen P of 30 in the first season, rather than the three seasons it took at Inniskillen.

\section{REFERENCES}

Clark, D.A.; Thom, E.R.; Waugh, C.D. 1996. Milk production from pastures and pasture silage with different levels of endophyte infection. Proceedings of the New Zealand Society of Animal Production 56: 292-296. 
